\title{
TEACHING PERFORMANCE IMPROVEMENT THROUGH THE APPLICATION OF KNOWLEDGE MANAGEMENT AND TEACHERS CAPACITY BUILDING
}

\author{
Suryadi \\ Department of Educational Administration \\ Universitas Pendidikan Indonesia, Indonesia \\ suryadi@upi.edu
}

\begin{abstract}
This study aimed to describe and analyze the knowledge management and capacity development of teachers. Analytic descriptive method with quantitative approach used in this study on 225 participant. The result: There is a significant effect simultaneously knowledge management, capacity building of teachers to teaching performance, knowledge management and capacity development of teachers are in the category enough. Personal dimension, procedures and technologies with category enough. Dimension policy, management, quality assurance, impact category enough.
\end{abstract}

Keyword: Knowledge management, capacity building, Teaching Performance

\section{INTRODUCTION}

Human resources is the most important asset in an organization because human resources have a role as the subject of the implementation of policies and operational activities of the organization. The existence of human resources is closely related to the performance of the organization, namely the ability to carry out the tasks assigned to the organization as well as possible in order to achieve the agreed targets.

Various problems and constraints relating to the condition of teachers, among others related to quality, fairness, teacher welfare and human resource management [9]. This is reinforced by the results of teacher competency test (UKG) in November 2015 which shows the average national UKG result of 53.05, while the government targets the average value in the number 55. In addition, the average professional value 54.77, while Average score of 48.94 pedagogic competencies.

Djoyonegoro's research (2004/2005), shows that only $43 \%$ of teachers in Indonesia are qualified professionals. the research of [8] shows that $76.6 \%$ of the students 'learning outcomes are influenced by the teaching performance of teachers, with details: teachers' ability to teach contributes $32.43 \%$, mastery of the subject matter contributes $32.38 \%$ Teachers on subjects contributed $8.60 \%$.
The purpose of this research is to know and analyze: (1) Description of knowledge management, teacher capacity building, teacher teaching performance; (2) Influence of knowledge management and teacher capacity development to teacher teaching performance as partial and simultaneous. Benefits for this research are: (1) schools can optimize knowledge management role to improve teaching performance for sustainability and sustainability of school; (2) school can optimize the role of teacher capacity building to improve teaching performance for sustainability and sustainability of school; (3) development of knowledge management knowledge and teacher capacity building to improve teaching performance

\section{METHODS}

Based on the variables studied then this research type is descriptive research and by quantitative method. The method of data analysis used in this research is path analysis because the researcher wants to ascertain whether there is any influence between the application of knowledge management and teacher capacity building to the teaching performance of the teacher.

The path analysis model is as follows:

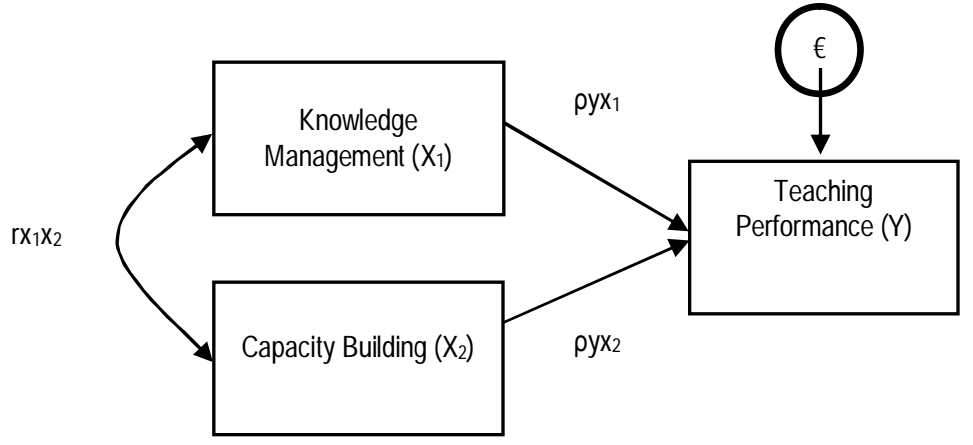

\section{RESULTS AND DISCUSSION}

First: It is known that the knowledge management variable has an average score of 3,262 means that the value is in the medium category or high enough. In this knowledge management variable the highest score is in the "personal" dimension with score 
3,343 and the lowest value is in the dimension of "Technology" with score 3,193.

This is encouraging because some of the benefits of applying knowledge management [10] are as follows: (1) knowing and realizing intangible asset values (2) having the opportunity to increase value added in the principal affairs process. (3) disseminate correct practice by sharing knowledge of individual knowledge and parts of the organization. This is in line with Goodhue who says that technology (ICT) acts as a medium that facilitates the dissemination of explicit knowledge, if used appropriately and has a match with the tasks that are supported it can have a positive impact on individual performance [2]

Furthermore [3] argues that in practice knowledge management can be a guide on the management of intangible assets that become pillars of the organization in creating value.

Second: Teacher capacity development variables have an average score of 3,245 means that the value is in the medium category or high enough. In this teacher capacity development dimension, the highest score is in the dimension of "PKG policy" with score 3,267 and the lowest score is in "PKG management" dimension with score 3,219 .
This dimension has an indicator of the policy process that concerns the concern of the head of the madrasah to the teacher's difficulties, how the head of the madrasah is able to develop alternative solutions and the ability to choose one of the best alternative which is used as policy solution to solve teacher problems and the ability of madrasah head to make Provision of teacher capacity building policy. Research in line with this is put forward by [7] that human resource development as a management intervention with the aim of improving organizational performance.

The service process should have the criteria as presented [5], namely the managerial capacity of the madrasah administrator, the structures and processes that provide feedback on staff work and decisionmaking at the madrasah. The sequence for developing teacher capacity building according to [1] that the first set to do in planning is 1) identification of the main problem, 2) researching the main causes, 3) determining the most influential causes, 4) Repair and set goals.

Third, based on the findings of the research indicates that the effect of knowledge management and teacher capacity building on teachers' teaching performance, the correlation is as follows:

\begin{tabular}{|c|c|c|c|c|}
\hline \multicolumn{5}{|l|}{ Correlations } \\
\hline & & $\begin{array}{l}\text { knowledge } \\
\text { management }\end{array}$ & \begin{tabular}{ll|}
$\begin{array}{l}\text { teacher } \\
\text { building }\end{array}$ & capacity \\
\end{tabular} & $\begin{array}{l}\text { teaching } \\
\text { performance }\end{array}$ \\
\hline \multirow[t]{3}{*}{$\begin{array}{l}\text { knowledge } \\
\text { management }\end{array}$} & $\begin{array}{l}\text { Pearson } \\
\text { Correlation }\end{array}$ & +2 & $.727^{* *}$ & $.463^{* *}$ \\
\hline & Sig. (2-tailed) & & .000 & .001 \\
\hline & $N$ & 225 & 225 & 225 \\
\hline \multirow[t]{3}{*}{$\begin{array}{l}\text { teacher capacity } \\
\text { building }\end{array}$} & $\begin{array}{l}\text { Pearson } \\
\text { Correlation }\end{array}$ & $.727^{* * *}$ & 1 & $.514^{* * *}$ \\
\hline & Sig. (2-tailed) & .000 & & .001 \\
\hline & $N$ & 225 & 225 & 225 \\
\hline \multirow[t]{3}{*}{ teaching performance } & $\begin{array}{l}\text { Pearson } \\
\text { Correlation }\end{array}$ & $.463^{* * *}$ & $.514^{* * *}$ & 1 \\
\hline & Sig. (2-tailed) & .001 & .001 & \\
\hline & $N$ & 225 & 225 & 225 \\
\hline
\end{tabular}

**. Correlation is significant at the 0.01 level (2-tailed).

The correlation between Knowledge Management variables (X1) and Teacher Capacity Building variables (X2) of 0.727 means having a high significance value is 0,000 which means less than 0.05 meaning that there is a significant correlation, (5) the correlation between Management variables Knowledge (X1) with the Teaching Teacher's Performance (Y) variable of 0.463 means having a high enough relationship, the significance value is 0.001 which means less than 0.05 which means that there is a significant correlation. The correlation between the Teacher Capacity Building variables (X2) With the variable Teaching Performance Teachers (Y) of 0.514 means have a high enough relationship significance value is 0.001 which means smaller than 0.05 which means that there is a significant correlation.

Calculation of path analysis in this study using SPSS assistance. Here are the results of SPSS calculation in path coefficients:

Coefficients $^{\mathrm{a}}$

\begin{tabular}{|c|c|c|c|c|c|c|c|}
\hline \multirow[b]{2}{*}{ Model } & \multicolumn{2}{|c|}{ Unstandardized Coefficients } & \multirow{2}{*}{$\begin{array}{l}\text { Standardized Coefficients } \\
\text { Beta }\end{array}$} & \multirow[b]{2}{*}{ t } & \multirow[b]{2}{*}{ Sig. } & \multicolumn{2}{|c|}{ Collinearity Statistics } \\
\hline & $\mathrm{B}$ & \begin{tabular}{|l|} 
Std. Error \\
\end{tabular} & & & & Tolerance & VIF \\
\hline \begin{tabular}{l|l} 
& (Constant) \\
\end{tabular} & 57.909 & 4.606 & & 12.573 & .000 & & \\
\hline knowledge manage & .417 & .105 & .119 & 1.788 & .000 & .996 & 1.004 \\
\hline teacher capacity building & .737 & .167 & .247 & 3.996 & .000 & .996 & 1.004 \\
\hline
\end{tabular}

Dependent Variable: teaching performance

This shows that knowledge management has influence of 0,119 to influence teacher teaching performance, while teacher capacity building (X2) has bigger influence than knowledge management variable equal to 0.247 in influencing teacher teaching performance. 


\begin{tabular}{|l|l|l|l|l|l|}
\hline Model & $\mathrm{R}$ & R Square & Adjusted R Square & $\begin{array}{l}\text { Std. Error of the } \\
\text { Estimate }\end{array}$ & Durbin-Watson \\
\hline 1 & $.727^{\mathrm{a}}$ & .516 & .507 & 9.941 & 1.591 \\
\hline
\end{tabular}

a. Predictors: (Constant), knowledge management, teacher capacity building

The above data shows that the mutual influence between knowledge management and teacher capacity building on teacher teaching performance is $0,516(\mathrm{R} 2=0.516)$.

In addition to the influence of knowledge management and teacher capacity building on teachers' teaching performance, there is also a probability of the emergence of the influence of other variables (residues) not present in this study. The major coefficient of influence path for other factors that are not in this research is $\rho y \_\varepsilon=\sqrt{ }(1-0.516)=\sqrt{ } 0,484=0.6957$.

The structural model of the influence of knowledge management, teacher capacity building on teachers' teaching performance is as follows:

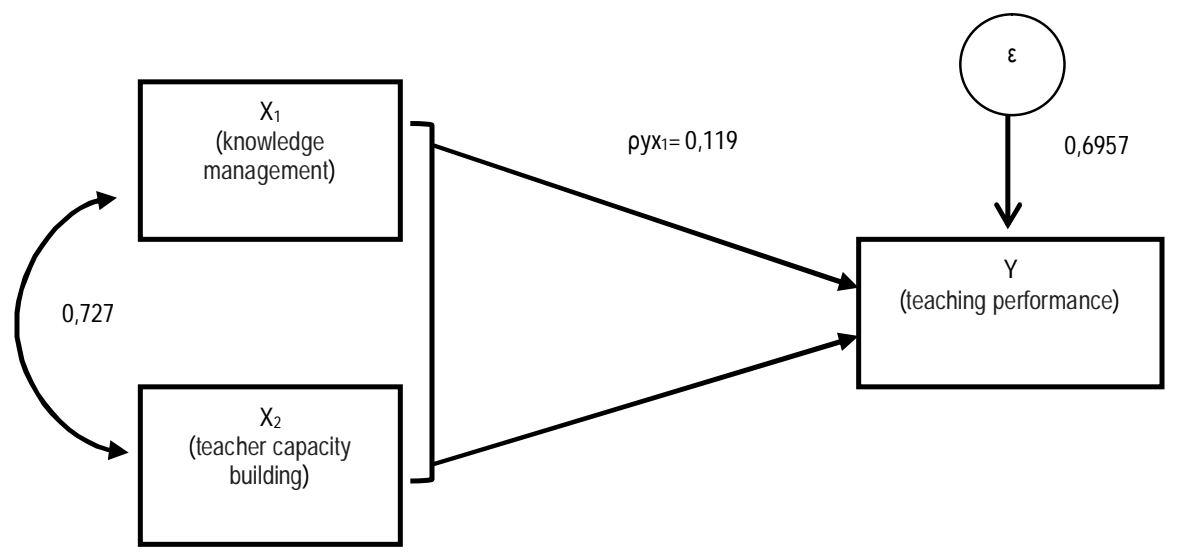

Regression equation $\hat{\mathrm{Y}}=57.909+0.417 \mathrm{X} 1+$ $0.737 \mathrm{X} 2$ with correlation coefficient value 0.727 which is in high category based on interpretation table correlation coefficient. The coefficient value of determination of knowledge management variables and teacher capacity development on teacher teaching performance of 0.516 . This figure shows that teacher teaching performance (Y) is influenced by knowledge management (X1) and teacher capacity building (X2) simultaneously (51.6\%). The empirical causal relationship between $\mathrm{X} 1, \mathrm{X} 2$ to $\mathrm{Y}$ can be made the structural equation as follows: $\rho \times 2 \varepsilon 1=\rho 21+\rho 21 \varepsilon 1=$ $0.516+0.696 \varepsilon 1$ while the rest of 0.6957 is influenced by other factors or epsilon.

Tests Significance of variables of teacher capacity development and knowledge management on teacher teaching performance variables, based on the results of table 2 . above note that the value of $t$ arithmetic of 12.573 with significance / probability 0.000 . So before making a decision must first compare between the value of $\mathrm{t}$ arithmetic with $\mathrm{t}$ table. If $\mathrm{t}$ arithmetic $\geq \mathrm{t}$ table then it can be said there is a significant influence and vice versa, $t$ arithmetic is 12.573 and $t$ its table in search with formula $(\alpha / 2$ : nk1 ) with level of trust $95 \%$ hence value $\alpha=0,05$. So $(0.05 / 2: 225-2-1)$ then searched in t table $(0.05$ : $222)=1.960$ so it can be concluded that: $t$ arithmetic $12,573 \geq$ from $t$ table $1.960=$ significant $0.000<0.05$ $=$ significant. Based on the results of the decision, the hypothesis in this research is the influence of knowledge management and teacher capacity development on teacher teaching performance can be accepted.

ICT technology acts as a medium that facilitates the dissemination of explicit knowledge, if utilized appropriately and has compatibility with tasks that are supported it can have a positive impact on individual performance [2]. The things that make these two factors affect the teaching performance of teachers in MA Bandung, among others, the interaction and communication between colleagues are well established, listening and understanding the wishes of the teachers, the opportunity given to teachers to demonstrate its capacity as a functional effective, building a system that directs teachers to collaborate, reflects on every work practice, is open to new thinking in teaching as well as learning, flexible, presents learning that suits the needs of learners

The performance of teachers appears to be responsible for carrying out the mandate, the profession it carries, and the morale it possesses, reflected in its adherence, commitment, and loyalty in developing the potential of learners and advancing the school [6]. "Creating a professional learning community" that is part of the madrasah's role in improving the capacity of teachers, as has been done by research and development of schools for a long time by experts (Du Four \& Eaker, 1998; Hord, 2003; 
Huffman \& Hipp, 2003; Martin-Kniep, 2003; Norris, Barnett, Basom, \& Yakes, 2002; Robert \& Pruitt, 2003; Senge, 1990; 2001; Wald \& Castlebery, 2000; Walsh \& Satetes, 200) in [4].

In the learning community activities of teachers in madrasah, knowledge sharing can be made regarding teacher's capacity in exploring their skills in the form of brainstorming with fellow teachers, dialogue with supervisors / supervisors on various knowledge not only coming from the top level. This activity can be done thoroughly / systemically [4].

\section{CONCLUSION}

The influence of knowledge management on teachers' teaching performance is moderately or moderately identified, the order of their correlation strength is on personal aspects, procedures and technology. The influence of teacher capacity building (PKG) on the teaching performance of teachers with moderate or sufficient category, the sequence of correlation strength is on the policy aspect, quality assurance, impact and management of PKG. The effect of teacher capacity building and knowledge management on teachers' teaching performance is high.

\section{REFERENCE}

[1] Gasperz, V. 2005. Total Quality Management. Jakarta: Gramedia.

[2] Goodhue, T. R. 1995. Task Technology and Fit Individual Performance. MIS Quarterly, 213-236.

[3] Honeycutt, J. 2002. Knowledge Management Strategies. New Jersey: Prentice Hall.

[4] Lunenburg, I. B. 2006. The Principalship: Vision to Action. Houston: Wadsworth Cengage Learning.

[5] Mart. 2013. Commitment to School and Student. International Journal of Academic Research in Business and Social Science, 336-340.

[6] Priansa, D. 2014. Kinerja dan Profesionalisme Guru. Bandung: Alfabeta.

[7] Stewart, R. H. 2007. Management Development. Lancester: Routledge.

[8] Sudjana. 2006. Metode Statistika. Bandung: Tarsito.

[9] Surya, M. 2007. Bunga Rampai Guru dan Pendidikan. Jakarta: Balai Pustaka.

[10] Sykrme, D. 2002, August 8. What's Next for Knowledge Management? Retrieved from skyrme.com. 